\title{
Between the Supernatural and the Natural: Ockham on Evident Judgements
}

\author{
Sonja Schierbaum ${ }^{1}$
}

Published online: 24 December 2016

(c) The Author(s) 2016. This article is published with open access at Springerlink.com

\begin{abstract}
Ockham defines intuition as the kind of cognition on the basis of which it is not only possible to evidently judge that a thing exists when it exists, but also that a thing does not exist when it does not exist. He makes a further distinction between natural intuition and supernatural intuition. The aim of this paper is to determine what, according to Ockham, can be judged evidently by means of natural intuition and what can only be judged evidently by means of supernatural intuition. It is commonly assumed that by natural intuition we can make only affirmative judgements, whereas by supernatural intuition we can make both affirmative and negative judgements. The paper shows that this way of contrasting the two is mistaken. The paper argues instead that also natural intuition, according to Ockham, enables us to make both affirmative and negative judgements.
\end{abstract}

Keywords Intuition of non-existents - Evident judgement · Divine omnipotence $\cdot$ Existence $\cdot$ Negative judgement

\section{Introduction}

According to our everyday notions, we can acquire beliefs, and even true ones, about things we perceive. This possibility is not confined to cases where what is believed is affirmative: seeing a rook on the roof, one can judge, and hence, come to believe not only that the rook is on the roof, but also that the rook is not in the tree. One of the

Sonja Schierbaum

sonjaoh@hotmail.com; sonja.schierbaum@uni-hamburg.de

1 Philosophisches Seminar der Universität Hamburg, VonMelle-Park 6, 20146 Hamburg, Germany philosopher's tasks is to give a systematical account of the relation between perception and the acquisition of (true) beliefs. The Franciscan William Ockham approaches this issue in terms of intuitive cognition and evident judgement: ${ }^{1}$ the former is a kind of (intellectual) perception on the basis of which one can judge correctly that the thing 'intuited' exists or that it is thus-and-so. The idea is that intuitive cognition, as a non-propositional cognition (partially) causes a propositional act of judging. ${ }^{2}$

Ockham calls this kind of judgement 'evident'. By definition, if an act of judging is evident, then what is judged is true. According to the Franciscan, what can be evidently judged can also be negative in form: one can judge evidently that (a) a thing does not exist or that (b) a thing is not thus-and-so-by means of intuitive cognition, or intuition, for short.

Ockham further distinguishes between 'natural' and 'supernatural intuition', thereby marking a crucial cognitive difference between acts of intuition that obtain by wholly natural means and those that occur only by divine intervention. It is commonly assumed in the secondary literature that by natural intuition we can make only affirmative judgements, whereas by supernatural intuition we can make both affirmative and negative judgements. This view, however, is mistaken, since by natural intuition we can make both affirmative and negative judgements, or so the paper argues.

Ockham's claim concerning the intuition of non-existent things has provoked a still ongoing debate in medieval

\footnotetext{
${ }^{1}$ For discussion of intuition see Adams (1987: 501-525), Day (1947, esp.146-174). Panaccio (1991: 116-120), Panaccio (2004: 5-8, 2010).

${ }^{2}$ I give a more detailed account of intuition and evident judgement in Sect. 2.1.
} 
scholarship centering on his basic attitude towards scepticism. As Panaccio and Piché have argued convincingly, the 'current consensus is that the traditional [sceptical] readings of Ockham in the first half of the twentieth century were generally misguided on these topics. ${ }^{3}$ Panaccio and Piché also defend the possibility of intuition of non-existents against scepticist interpretations. ${ }^{4}$ By focussing on this supernatural intuition of non-existents, however, it is easily overlooked that within Ockham's theoretical framework it is also possible to make certain evident negative judgements on a wholly natural cognitive basis. Take the two forms of negative evident judgements that (a) a thing does not exist or that (b) a thing is not thus-andso. These are not on a par with respect to their cognitive requirements, since (a) requires the supernaturally achieved intuition of a non-existent thing, whereas (b) does not involve any supernatural cognition. In this paper, therefore, I pay special attention to both supernatural and natural cases where what is judged takes for example the form ' $a$ is not $F$ ' or ' $a$ does not exist'.

As I see it, the scope of what can be evidently judged by wholly natural means is restricted to the very presence or absence of things and their presently being thus-and-so or not being thus-and-so. ${ }^{6}$ By contrast, evident judgements concerning either the mere existence of a thing, where this existential judgement does not entail any judgement about the thing's presence, or the non-existence of a thing are unattainable without God's intervention, that is, without supernaturally induced acts of intuition. Thus it should be noted that evident judgements can differ with respect to their scope although they do not differ as to their form.

\footnotetext{
3 Panaccio and Piché (2010: 98). Such sceptical readings include Michalsky (1921), Gilson (1937, esp. 61-91), Pegis (1944); early critics of this sceptical interpretation are Boehner $(1943,1945)$ and Day (1947). More recent critics of the sceptical interpretation include Karger (1999, 2004) and Panaccio and Piché (2010).

4 According to Panaccio and Piché, it can be seen as being more in line with a strong reliabilist picture involving certain counterfactuals (Panaccio and Piché 2010: 112-116). In this paper, however, my primary concern is not to add to the project of meeting the sceptical worries arising from this possibility.

${ }^{5}$ I remain silent on the question whether for Ockham accepting something as true and rejecting something as false are different kinds of acts or whether the latter act can be reduced to the former. Ockham presents and discusses his account of judgement, that is, of assent and dissent in Ockham, Quodlibeta [hereafter: Quodl.] III, q.8 (OTh IX, 232-237); Quodl. V, q.6 (OTh IX, 500-503). Assent corresponds to the act of accepting something (as true) whereas dissent corresponds to the act of rejecting something (as false). See Ordinatio [hereafter: Ord.] I, prol., q.1 (OTh I, 16-18). For discussion of Ockham's theory of judgement see Brower-Toland (2007, 2015), Karger (1995), Panaccio (2009), Schierbaum (2014: 190-202; 203-214).

${ }^{6}$ Note that although intuition, due to its specific causal powers, is an important element of the cognitive basis of natural evident judgements, it does not exhaust this basis. I say more on this basis in Sect. 2.2.
}

I proceed as follows: I first discuss Ockham's paradigmatic presentation of natural intuition and evident judgement, both affirmative and negative (Sects. 2.1, 2.2 respectively) and then turn to the supernatural cases (Sects. 3.1, 3.2). Against this background, I finally come to an assessment of the general relation between the natural and the supernatural cases of evident judgement (Sect. 4).

\section{Intuition and Evident Judgement: The Natural Paradigm}

\subsection{The Natural Affirmative Cases}

Ockham introduces the possibility of acquiring evident knowledge that a thing exists along with the possibility of acquiring evident knowledge that a thing does not exist. $\mathrm{He}$ writes:

[...] the intuitive cognition of a thing is such a cognition by virtue of which it can be known whether a thing exists or not, such that if the thing exists, the intellect judges immediately that it exists and evidently recognizes that it exists, [...]. And in the same way, if by divine power such a [...] cognition of a non-existent thing were to be preserved, then by virtue of this non-complex cognition the intellect would evidently cognize that this thing does not exist. $^{7}$

In the natural course of the world, if a subject has an intuition of a thing $a$, then $a$ is the efficient cause of this act. $^{8}$ The intuition is 'proper' (propria) to the thing that causes it insofar as an intuition is individuated by its cause. It is only an intuition of the very thing that causes it, of nothing else. As Ockham states in an often-quoted passage in the Quodlibeta:

[Intuitive cognition] is proper to particulars [...] because it is immediately caused by a particular thing or is apt to be caused, and cannot be caused by another thing, [...]. ${ }^{9}$

\footnotetext{
7 Ord. I, prol., q.1 (OTh 1, 31), (italics mine).

8 Three terminological remarks are in place here. First, throughout this paper, I shall use 'act of intuitive cognition', 'intuitive act' and 'intuition' interchangeably. So when I speak of an intuition, I thereby mean an act of intuitive cognition. Second, from now on, when I speak of a cause tout court, I mean an efficient cause, since in the present context we are exclusively dealing with efficient causes. For Ockham's conception of efficient causality see Adams (1987: 741-798). Third, throughout this paper, by 'judgement' I refer to the act of judging, not to what is judged, if not indicated otherwise. ${ }^{9}$ Quodl. I, q.13 (OTh IX, 73).
} 
Ockham emphasizes that an intuition of $a$ cannot be caused by a thing $b$, no matter how much $a$ and $b$ are alike. ${ }^{10}$ This illustrates that an intuitive act is exclusively individuated by its cause. It also gives us the following sufficient condition for a subject's intuiting a thing $a$ in the natural order of things:

(1) If a thing $a$ causes an intuition in a subject $S$, then $S$ intuits $a$.

Now if the subject intuits $a$, then the subject is in a position to correctly judge that $a$ exists ( $a$ est): that this act of judging is 'evident' means that—by definition-what is judged is true. Also, Ockham states that 'the intellect judges immediately (statim)'. This is to say that intuitionbased thoughts leave no room for lack of truth commitment: ${ }^{11}$ the subject cannot merely entertain the thought that a thing exists if he has an intuition of the thing in question.

Note that what can be judged in this way can take different forms. Why? The general idea is that things are normally not intuited in isolation, or one-by-one, but (a) in relation to their spatial and temporal position ("here and now') as well as (b) in relation to other things in their vicinity; analogously, it is not possible to perceive just one particular thing in total isolation: if two rooks are sitting next to each other on the roof, then, under normal lightning conditions etc., I do not only see one of the rooks, but both of them, together with the things in their surroundings, e.g., (part of) the roof. As to (a), even if, say, in an art exhibition, someone is intuiting only one thing, say, a sculpture in an otherwise empty room, then he nevertheless intuits the sculpture in relation to the walls, the floor, in short, with respect to its position not only in space, but also with respect to its position in time, that is, as being present (to him) now. In Ockham's own words:

I say that the intellect cognizes intuitively particular things as to here and now and with respect to all conditions under which the senses cognize $\left[\ldots . .{ }^{12}\right.$

The point is that it is possible to entertain more than one thought on the basis of one and the same intuitive act. And which thought the subject comes to entertain also depends on factors such as the subject's attention or other

\footnotetext{
10 'Unde propter similitudinem non plus dicitur intuitiva propria cognitio singularis quam abstractiva prima, sed solum propter causalitatem, [...]' Quodl. I, q.13 (OTh IX, 76). Ockham's point here is that intuition is a genuine singular cognition due to its acts being individuated by their singular causes; intuition is not singular because an intuitive cognition would be a representation of just one particular. For a discussion of the representational function of 'similitude' or 'likeness' see Panaccio (2004: 119-144).

${ }^{11}$ I owe this formulation to Wolfgang Künne. See Künne (1995: 370).

${ }^{12}$ Rep. II, qq.12-13, (OTh V, 284).
}

preoccupations. ${ }^{13}$ If, however, the thought the subject is entertaining is about $a$ while he is intuiting $a$, then the thought is immediately accepted (as true). Now due to the natural cognitive situation it is not possible that someone who judges evidently that $a$ exists while intuiting $a$ would not be ready to judge that $a$ is present (to him), since he can only judge evidently that $a$ exists in the very presence of $a$. We rarely-if ever-acknowledge the mere existence of a thing ('this thing exists'). ${ }^{14}$ On some occasions, however, we do state a thing's being present (to us), that is, its being 'here and now'. ${ }^{15}$ Consider the following scenario. Looking for her glasses, Anne (in the kitchen) asks Peter (in the living room): 'Can you spot my glasses?' And Peter, seeing ('intuiting') the glasses on the table, answers, 'Yes, they are here.' This case of an existential judgement seems to be a fairly natural one. And it seems that Ockham has cases such as these in mind when he speaks of natural affirmative evident judgements about things. Thus:

(2) If a subject $\mathrm{S}$ judges evidently that $a$ exists while intuiting $a$ in the presence of $a$, then $\mathrm{S}$ is ready to judge evidently that $a$ is here or that $a$ is present. ${ }^{16}$

It is important to keep this in mind when it comes to supernaturally induced 'affirmative' judgements, since in the supernatural case, the subject is not ready to judge that the thing is present or that it is here.

Speaking in terms of causal powers, everything present to a subject can act on him as a cause of an intuitive act. Therefore, the complete cause of an intuition can be rather complex, e.g. if several things causally act on a subject simultaneously. This is even the case where there is apparently only one thing, such as a sculpture, in a room. According to Ockham, there are only particular things and everything that exists or can exist is either a substance (Socrates, this rook) or a quality of a

\footnotetext{
${ }^{13}$ Ockham also states that the forming of such a thought "can only occur by means of the will'. Ord. I, dist.3, 1.4 (OTh II, 438). I do not take this to mean that it is totally 'up to the subject' to choose which thought to entertain. The point is that there are several factors that determine the 'forming' of a thought, of which some might be 'up to the subject', whereas others are not. For a discussion of these factors see Schierbaum (2014: 209-212).

${ }^{14}$ Carl stresses the redundancy of propositions of the form 'This is an $F$ '. He says: 'Die Merkwürdigkeit eines solchen Satzes ergibt sich daraus, dass es völlig überflüssig ist, etwa im Anblick einer bestimmten Person zu sagen, sie existiere. Denn, gegeben gewisse Umstände, so ist diese Situation die Situation, in der die Wahrheit dieses Satzes offenkundig ist, und die Behauptung dieses Satzes daher überflüssig ist.' Carl (1974: 187, fn.14).

15 The presence of a thing implies its existence, but the reverse, of course, does not hold.

${ }^{16}$ I decided to render the forms of the judgement about a thing's presence in this way because they are quite natural in English. The two forms should cover all cases in which something is present to the judging subject, that is, 'demonstratively' locatable in space and/or time ('here and now'). The copula 'is' here is a further indexical element referring to the present time ('now').
} 
substance (Socrates' being wise, the rook's being black). ${ }^{17}$ Normally, it is not possible to intuit a substance without at least some of its qualities. ${ }^{18}$ For instance, when I intuit a rook in plain daylight etc., then I also intuit some its qualities such as the black colour of its feathers. For this reason, it is possible to evidently judge about one and the same things in different respects on the basis of one and the same intuitive act. In a passage immediately subsequent to the very introduction of intuition Ockham writes:

Similarly, intuitive cognition is such that when certain things are cognized and one of them (I) inheres in another or (II) is located in a different place to another or (III) relates to another thing in any other way, then it is known immediately by virtue of the non-complex cognition of these things whether (I') the thing inheres (in another thing) or not, whether (II') it is located in a different place or not, and (III') the same applies with respect to any other contingent truth [...]. ${ }^{19}$

We can generalize three forms of what can be evidently judged - affirmatively or negatively — on the basis of natural intuition. As we saw earlier, it is possible to judge about a thing's being present on the basis of an intuition of that thing. The form of this judgement can be rendered as follows:

(A) $\quad a$ is (not) here. ${ }^{20}$

A judgement about one thing inhering in another-(I') in the quotation-can be of the following form:

(B) $\quad a$ is (not) $F$.

Lastly, (II') and (III'), that is, judgements about things standing in a spatial relation or in another kind of relation to each other can be of the following form:

\section{(C) $a($ not)R $b$.}

It should have become clear that due to the referential complexity of intuition, what can be evidently judged also covers different aspects of the thing or things intuited and thus, can take different forms.

\footnotetext{
17 '[...] quia nulla res est quin sit substantia vel accidens; [...].' Summa Logicae [hereafter: SL] I, 38 (OPh I, 108).

${ }^{18}$ For the ease of exposition, I leave aside the complication that for Ockham we have direct cognitive access by intuition only to accidents, but not to substances. In some passages he explicitly states that we come to have a cognition of substances via the intuition of their accidents: Rep. IV, q.2, (OTh VII, 23): '[...] per cognitionem intuitivam alicuius accidentis absoluti devenitur in cognitionem subiecti, puta quod ibi est subiectum sustentans accidens [...]' According to this view, then, it is not naturally possible to intuit a particular substance (Socrates) without at least some of its accidents.

19 Ord. I, prol., q.1 (OTh I, 31). It is immediately subsequent to the quote in fn. 5 .

${ }^{20}$ The judgement could also be of the form ' $a$ is (not) present'. See fn.16.
}

Now what exactly does it mean that 'by virtue of' the intuition a subject can evidently judge about the things intuited in different respects? The relation thereby expressed is, again, nothing but a causal relation: the intuition of $a$ causes the act of evidently judging that $a$ exists. In the natural affirmative case, the intuition of a thing, say, a rook causes the act of judging that the rook exists in conjunction with the rook itself. The intuition is only a partial cause of the judgement, the rook acting as another cause of the act of judging evidently that the rook exists. One could also say that the rook's causal contribution to the judgement is indirect insofar as it directly causes the intuition of the rook which, in turn, directly causes the judgement. The natural act of judging that $a$ exists and the supernatural act of judging that $a$ does not exist differ in the composition of their respective cause. The underlying idea is that something in conjunction with something else can cause an effect opposite to the one it would produce by itself. Ockham writes:

It is not contradictory that some cause in connection with another partial cause causes some effect, but that the former without the other partial cause produces the opposite effect. [...] I concede that the cause of these judgements [that the thing exists or that it does not exist] is not the same, because the cause of the one [that the thing does not exist] is the cognition without the thing, and the cause of the other [that the thing exists] is the cognition along with the thing as a partial cause. $^{21}$

It is possible to reconstruct the following causal chain in the natural affirmative case: First, a thing $a$ causes an intuition of $a$ within a subject, and then $a$ and the intuition of $a$ jointly cause the evident act of judging that $a$ exists. In the supernatural negative case, the-supernaturally sustained-intuition of $a$ (without $a$ ) causes the evident act of judging that $a$ does not exist. This is the 'opposite effect' insofar as what is judged in this case ('that $a$ does not exist') and what is judged in the former case ('that $a$ exists') are contradictory. I discuss the supernatural negative case in some detail later. ${ }^{22}$

Natural affirmative cases taking one of the forms of (B) or (C) can be described analogously to the former causal chain. ${ }^{23}$ Let us briefly review them. As to (B), by naturally intuiting a rook, Anne normally intuits also some of the rook's qualities (its blackness for instance), such that she is able to evidently judge that (B) the rook is black. ${ }^{24}$

\footnotetext{
${ }^{21}$ Ord. I, prol., q.1 (OTh I, 71).

22 See Sect. 3.2.

23 (B) $a$ is (not) $F$, (C) $a$ (not)R $b$.

${ }^{24}$ Ockham calls the relation a quality bears to its subject a relation of 'inherence'.
} 
Put differently, it is necessary to intuit a thing together with one of its qualities in order to evidently judge that that thing is thus-and-so. As to (C), Anne can also judge about for instance the rook's spatial relation to other things. For instance, she can judge that the rook is on the roof. Just as it is necessary to intuit $a$ in order to evidently judge that $a$ is here it is necessary to have an intuition of two things $a$ and $b$ in order to evidently judge that $a$ relates to $b$ in a certain way. For instance, Anne can evidently judge that the two halves of the cheesecake are equal only if she intuits both halves of the cake simultaneously. The following diagram can be given for affirmative natural evident judgements. $^{25}$ The decisive point is that the causal relations obtain simultaneously. Thus:

$$
\begin{array}{r}
a \rightarrow \mathrm{I}(a) \rightarrow \operatorname{Judg}(\text { ' } a \text { is here') })_{\mathrm{ev}} \\
\text { Attention, preoccupation }
\end{array}
$$

\section{DIAGRAM 1}

This illustrates that the intuition of $a$-together with $a$ causes the act of judging correctly about what is thought in the very presence of $a$. Which of the possible thoughts are entertained depends on the subject's attention and preoccupation. Now does this diagram also apply if what is judged is of one of the three negative forms?

\subsection{The Natural Negative Cases}

One of the rare examples Ockham actually gives of such a case is the following:

[...] for instance, if I see simultaneously a whiteness and a blackness in one single act of intellectual cognition, and then I form this complex '[the] white [thing] is not black' ('album non est nigrum') by means of this intuitive cognition, I have only two acts: one intuitive [act] aimed at the whiteness and the blackness and another complex [act] [...] that is aimed at the copula and the terms negatively. ${ }^{26}$

Several remarks are in place here. First: In this passage, Ockham is primarily concerned with the question of how many acts are involved in the 'forming' of such a thought (a 'complex'). Therefore, he does not repeat that if this kind of thought is 'formed' while intuiting both something white and something black it is at once accepted as true. Second, it becomes clear once more that more than one thing can be intuited in one intuitive act, where the intuitive

\footnotetext{
$\overline{25}$ The arrow ' $\rightarrow$ ' here denotes a causal relation: it is to be read 'causes'. 'I (a)' reads 'intuition of $a$ '. Of course, what is judged could also take the form ' $a$ is here' or simply ' $a$ exists'.

${ }^{26}$ Rep. II, qq.12-13 (OTh V, 280-281). (Italics mine).
}

act is distinct from the entertaining of a thought about the things intuited. In Ockham's example, the subject evidently judges that

\section{(I) [the] white thing is not black. ${ }^{27}$}

On the same cognitive basis, the subject could also judge that

(II) [this] whiteness is not identical to [this] blackness. Again, it might depend on the subject's preoccupation and attention on which of the aspects of what is intuited he focuses: whether he focuses on the qualities as particulars while neglecting the substance having the quality or whether he focuses on just this relation of a substance to its qualities. More generally, it should also be possible to judge evidently that one particular is not related to another particular in a certain way while intuiting both particulars at once. (See (C) above).

Suppose that what is judged is of the form ' $a$ is not here' (see (A) above)? The problem is that in the natural case, there simply is no intuition of $a$, if $a$ is not present. I would like to apply here Fred Dretske's idea that-at least with respect to some relations, especially spatial ones-it is possible to see in a primary epistemic way that one particular is not related to another particular in a certain way by seeing only one of them. ${ }^{28}$ This, of course, presupposes that the subject has some notion of the particular he has no intuition of. Ockham distinguishes another kind of singular cognition from intuition, namely the so-called abstractive cognition. By abstractive cognition, Ockham explains a subject's ability to think about a particular in its absence,

\footnotetext{
27 One might wonder why Ockham first says that two qualities 'whiteness' (albedo) and 'blackness' (nigredo) are intuited, but then speaks of something white (album) and something black (nigrum). The semantically relevant difference is that a term such as 'whiteness', as a so-called 'absolute term', can stand ('supposit') within a proposition for all and only the things it signifies, that is, for particularized qualities of 'whiteness', whereas a so-called connotative term such as 'white' can stand within a proposition for the things (the substances) having that quality, that is, for the things it 'primarily' signifies. 'White' secondarily signifies the quality of whiteness. Ockham presents the distinction between absolute and connotative terms in $S L \mathrm{I}, 10(\mathrm{OPh} \mathrm{I}, 36)$. For discussion, see Panaccio (2004: 64-83) and Schierbaum (2014: 21-37).

${ }^{28}$ See Dretske (1969: 151-152). I think the adaption of one of Dretske's cases here is sufficiently justified by the fact that his basic conception of primary epistemic seeing that something is the case bears important similarities to Ockham's conception of evident judgements based on intuition. Dretske's basic idea is that there are cases where a subject can be said to see that a thing $a$ is $P$ by seeing $a$ itself, where ' $P$ ' is a non-relational predicate. See ibid., p. 78. Dretske describes this as a situation where knowledge is acquired by visual means. Ibid., p. 80. Analogously, Ockham could say that by intuiting things in their very presence, one can acquire knowledge about them and their properties. Adapting Dretske's solution for 'negative cases' indicates an elegant way of dealing with cases Ockham does not address himself directly while respecting his overall conception.
} 
that is, after it has been intuited by him. If I once had an intuition of Socrates, then if he is no longer present to me, I can think of him nevertheless, because, as Ockham says,

I saw him with such a shape, color, of such a height, breadth, and in such a place; and by this composite conception (conceptum compositum) I remember that I saw Socrates. $^{29}$

This 'abstractive cognition' of a particular-other than the intuition of it-is composite. This means that it has (conceptual) parts. These can be rendered explicit by way of a description of the thing. ${ }^{30}$ Most importantly, this singular abstractive cognition differs from intuition in that only intuition, but not abstractive cognition has the power of (partially) causing an evident act of judging about a thing's existence or its presently being thus-and-so. Abstractive cognition has no such causal powers. Ockham characterizes abstractive cognition as follows:

Abstractive cognition is that cognition by means of which it cannot be known of a contingent thing whether it exists or not. And in this way abstractive cognition abstracts from existence and non-existence, since neither can one evidently know by means of it that a thing exists when it exists nor that it does not exist when it does not, as opposed to intuitive cognition. $^{31}$

I would like to adapt one of Dretske's examples according to which it is possible to see in a primary epistemic way that a particular person is not in her room just by seeing either the person (without her room) or her room (without the person) to Ockham's conception. Consider Anne and Peter again. Suppose Anne is able to think of Peter in his absence because she intuited him many times such that she also acquired some singular 'abstractive conception' of him. ${ }^{32}$ Now in her search for Peter, Anne intuits the living room, but not Peter. Her

\footnotetext{
29 Quodl. I, q.13 (OTh IX, 77).

30 To avoid confusion: An act of intuition is not composite, but simple according to Ockham, because it does not contain other acts as parts. That is, the (possible) complexity of the complete cause of an intuition does not imply the (structural) complexity of the intuitive act.

31 'Notitia autem abstractiva est illa virtute cuius de re contingente non potest sciri evidenter utrum sit vel non sit. Et per istum modum notitia abstractiva abstrahit ab exsistentia et non exsistentia, quia nec per ipsam potest evidenter sciri de re existente quod exsistit, nec de non existente quod non exsistit, per oppositum ad notitiam intuitivam.' Ord. I, prol., q.1 (OTh I, 32).

32 That she has some such notion of Peter might become apparent by the fact that she is able to give a description of Peter including the way he looks, moves, talks and so on. At this point, it can remain open what this description exactly includes. Of course, Anne's abstractive singular notion of Peter can differ (and even strongly) from the abstractive notion another person might have of Peter.
}

intuition does not include Peter. One could say that her focus of attention is shaped by her preoccupation of finding Peter. Therefore she is willing to pay special attention to any Peter-like-aspect of her intuition. It is plausible that if Anne now thinks that

\section{(III) Peter is not here,}

she cannot but accept this thought as true because she has an intuition of the living room to which she refers to as 'here' while lacking an intuition of Peter at the same time. Put differently, her thought is partly based on the intuition of the living room and partly on her abstractive cognition of Peter.

One might worry that the involvement of abstractive cognition in this case changes things, and even radically. ${ }^{33}$ But in what respect? Of course, Anne could certainly not entertain the thought that Peter is not here without having some abstractive cognition of Peter. However, I see no reason why the causal powers of the abstractive cognition could change the overall causal picture sketched so far-simply because abstractive cognition, as noted before, altogether lacks causal powers with respect to the present-tense evident judgements discussed here. Abstractive cognition is relevant as to the content of the judgement; but since it is possible to think that $a$ is thus-and-so on the sole basis of abstractive cognition, but not to evidently judge that $a$ is thus-and-so on that basis, abstractive cognition, in this respect at least, is causally irrelevant.

In other words, I think there is no reason to suppose that in this case, the intuition of the living room could not be a (partial) cause of the evident judgement that Peter is not here (in the living room). ${ }^{34}$ If this is plausible, it can be held in general that if a subject has an intuition of $a$ (or of $b$ ) but merely an abstractive cognition of $b$ (or of $a$ ), then what he can evidently judge about $a$ (or $a$ and $b$ ) can be of one of the negative forms:
(A) $a$ is not here.
(B) $a$ is not $F$.
(C) $a \operatorname{notR} b$.

\footnotetext{
${ }^{33}$ I thank one of the anonymous reviewers for articulating this worry. ${ }^{34}$ As the same reviewer also points out, it is true that Ockham himself, at least to my knowledge, does not explicitly discuss such a case. Nonetheless, though, I see no reason why this analysis should contradict anything in Ockham's theory. In other words, Ockham holds that intuitive acts can be combined with other non-intuitive acts, and in a variety of ways. As a matter of fact, any complex mental act has non-complex acts as its parts of which intuition can be one. See Ord. I, prol., q.1 (OTh I, 16-18). Panaccio discusses another telling example in Panaccio (2004: 14). The point, as I see it, is that only intuitive acts exert this kind of causal powers, as opposed to any kind of abstractive act.
} 
The diagram can be adjusted as follows to the case of natural negative evident judgement: ${ }^{35}$

$$
\begin{gathered}
\mathrm{A}(b) \\
\vdots \\
a \rightarrow \mathrm{I}(a) \rightarrow \operatorname{Judg}\left({ }^{\prime} a \text { is } \text { not here }^{\uparrow}\right)_{\mathrm{ev}} \\
\text { Attention, preoccupation }
\end{gathered}
$$

\section{DIAGRAM 2}

It should have become clear that the fact that certain thoughts about absent things involve abstractive cognition in Ockham's picture does not affect the point that in the 'negative' cases discussed here the naturally induced intuition of a thing or things causes evident judgements. ${ }^{36}$ These acts of judging occur by wholly natural means. I now turn to the supernatural cases.

\section{Intuition and Evident Judgement: The Supernatural Paradigm}

\subsection{The Supernatural Negative Case}

Recall that Ockham introduces the possibility of acquiring evident knowledge about a thing's existence along with the-exclusively supernatural-possibility of acquiring such knowledge about a thing's non-existence. For this reason, I start the exposition of the supernatural paradigm with the negative case. I quote again the relevant passage:

[...] the intuitive cognition of a thing is such a cognition by virtue of which it can be known whether a thing exists or not, such that if the thing exists, the intellect judges immediately that it exists and evidently recognizes that it exists, [...]. And in the same way, if by divine power such a [...] cognition of a non-existent thing were to be preserved, then by virtue of this non-complex cognition the intellect would evidently cognize that this thing does not exist. $^{37}$

In the supernatural case described here, the intuitive act is attainable only by divine intervention, since the thing does not exist. The idea, as indicated above, is that thesupernaturally sustained-intuition of $a$ (without $a$ ) causes

\footnotetext{
35 I use the broken line to indicate that the 'forming' of the thought presupposes some abstractive cognition of $b$, noted as 'A $(b)$ ', without implying a causal relation between the abstractive cognition and the act of judging evidently that $b$ is not here.

${ }^{36}$ Again, what is thus judged could also take one of the two other forms distinguished in Sect. 2.1.

37 Ord. I., prol., q.1 (OTh 1, 31), (italics mine). See above, Sect. 2.1, first quote.
}

the evident judgement that $a$ does not exist. ${ }^{38}$ I suggest thinking of the conditional-if $[\ldots]$ a $[\ldots]$ cognition of a non-existent $[\ldots]$ were to be preserved, then [...] the intellect would evidently cognize that this thing does not exist-in the sense of a (true) counterfactual conditional. In the Latin text, Ockham uses subjunctive forms of the imperfect (esset, cognosceret). This indicates that he takes the content of the antecedent as quite exceptional, or contrary to the ordinary course of the world. ${ }^{39}$

Two metaphysical principles apply here. Both are related to divine omnipotence. The first concerns replaceability of any efficient cause by God. ${ }^{40}$ The second relates to the ontological separability of any two distinct things (res absolutae). According to Panaccio and Piché, these two principles illustrate what it amounts to that God's power be restricted only by what is contradictory. ${ }^{41}$ Applying the first principle to intuition, it means that God can act as a cause in place of any particular $a$ and cause an intuition of $a$ within the subject directly-even though $a$ might not exist. $^{42}$ Note that Ockham speaks of the 'preservation' of such an intuitive cognition in this case. Medieval authors distinguish between the (initial) causation of an effect and the preservation of that effect by its cause. For instance, the natural intuition of a rook is not only initially caused, but also sustained by the rook. If the rook is no longer present to the subject and thus, cannot sustain the intuition further, the intuition of the rook ceases to exist-unless God were to replace the rook as a cause such that the intuition would be sustained further. This suggests that in his introduction of the intuition of non-existents, Ockham has in mind the case where the thing no longer exists. Applying now the second principle, the point is that God can replace $a$ as a cause only because $a$ and the intuition of $a$ are 'really' distinct. Two things are distinct in this sense if and only if the one can exist without the other. Ockham specifies this a little further by stating that

$[\ldots]$ an intuitive vision, $[\ldots]$ is an absolute thing distinct in place and subject from the object that is

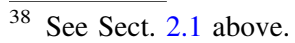

39 To my knowledge, this is Ockham's standard practice as regards the use of subjunctive forms in conditionals.

$40[\ldots]$ 'quidquid Deus producit mediantibus causis secundis, potest immediate sine illis producere et conservare'.' Quodl. VI, q. 6 (OTh IX, 604-605). 'Secondary causes' are nothing but 'natural' efficient causes, the point being that God is the primary cause of everything. See Rep. II, q. 3 (OTh V, 60). '[...] Deus est causa prima et immediata omnium quae producuntur a causas secundis.'.

${ }^{41}$ On the motivational role of these principles for Ockham's development of the doctrine of the intuition of non-existents see Panaccio and Piché (2010: 102-105).

42 '[...] sed in notititiam intuitivam corporalem potest mediante obiecto; igitur potest in eam immediate per se.' Quodl. VI, q. 6 (OTh IX, 605).
} 
seen; therefore the vision [of a star] can remain while the star is destroyed. ${ }^{43}$

There seem to be two criteria for distinctness: (a) difference in place and (b) difference in subject. The former should be clear: if $a$ and $b$ are not in the same place (at the same time), then $a$ and $b$ are distinct. What about (b)? A quality, as an absolute thing, inheres in a subject, without being itself a subject of further qualities. A substance, by contrast, is itself a subject of qualities. Thus if $a$ and $b$ are either not qualities of the same subject or if $a$ and $b$ are not the same substance, then $a$ and $b$ are distinct. An intuitive act and its object are distinct in both respects: they are (a) locally distinct and (b) distinct as to their subject: the intuitive act is a quality of the 'cognizing' substance whereas the thing intuited is either itself a substance or a quality of the 'cognized' substance. ${ }^{44}$ Modifying (1) above, it can be said that ${ }^{45}$

(1a) if a thing $a$ causes an intuition of $a$ in a subject $S$, then (A) $\mathrm{S}$ intuits $a$ as long as the intuition of $a$ in $\mathrm{S}$ is sustained by $a$ or (B) $\mathrm{S}$ intuits $\mathrm{s}_{\mathrm{sn}} a$ as long as the intuition of $a$ in $\mathrm{S}$ is supernaturally sustained by God (where $a$ is either absent or has ceased to exist). ${ }^{46}$

It is crucial that the naturally and the supernaturally sustained intuitive acts differ as to their causal powers with respect to evident judgements. Whereas in the natural, affirmative case, the intuition of $a$ together with $a$ causes an evident act of judging if what is thought is affirmative (See DIAGRAM 1 above), the supernatural negative case can be rendered as follows:

\footnotetext{
43 Ord. I., prol., q.1, (OTh 1, 39).

44 Things are complicated by the fact that Ockham also seems to admit of the possibility of intuiting one's own mental acts. Ord. I, prol., q.1 (OTh I, 39-44). If, however, it is correct to say that two mental acts inhere in the same subject, that is, the same intellective soul then they are not distinct with respect to (b). See McCord Adams (2001) and Perler (2010) for an account of Ockham's model of the soul.

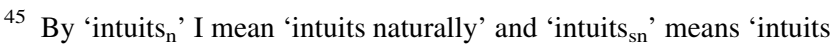
supernaturally'.

46 Apparently, Ockham is committed to the view that there are (and even only) particular possible things. In both cases the subject is said to have an intuition of $a$-even if $a$ does not exist. In that case, the subject must have an intuition of a possible particular thing, namely $a$, otherwise, the intuition would simply be of nothing. Cf. Panaccio and Piche (2010: 101). What further supports the assumption that intuition is restricted to things both actual and possible is this: according to Ockham, there is no intuition of impossible things such as the chimera. '[...] dico quod contradictio est quod visio sit, et tamen quod illud quod videtur non sit in effectu nec esse possit. Ideo contradictio est quod chimaera videatur intuitive, sed non est contradictio quod illud quod videtur nihil sit in actu extra causam suam, dummodo possit esse in effectu vel aliquando fuit in rerum naturam.' Quodl. VI, q.7 (OTh IX, 606-607).
}

$$
\begin{aligned}
& \text { God } \\
& \downarrow \\
& \mathrm{I}(a) \rightarrow \text { Judg (' } a \text { does not exist') })_{\mathrm{ev}} \\
& \uparrow \\
& \text { (Attention, preoccupation) }
\end{aligned}
$$

DIAGRAM 3

Here the limits of God's power become apparent: to judge that $a$ exists when $a$ does not exist would be contradictory. Such an act of judging could not be evident, since by definition, an evident act implies the truth of what is thus judged. Therefore, Ockham could argue, God can only replace the non-existent thing as a cause of an act of intuition, but he cannot replace the thing as a cause in the production of the act of judging, if what is judged is that the thing exists. This applies only to evident judgement, not intuitive cognition. In other words, not every cause is replaceable in every respect in view of the limits of divine power: a particular $a$ is replaceable in every situation with respect to its 'immediate' power to cause an act of intuition within a subject, but it is not replaceable in every situation with respect to its 'mediate' power to cause an evident act of judging. By natural means, it is not at all possible to evidently judge that a thing does not exist, since it is not possible to have an intuition of a thing that does not exist at present. Taking into account the distinction between initial causation and preservation, there are four possible combinations of naturally and supernaturally induced intuitive $\operatorname{acts}^{47}$ :

\section{INTUITION of a particular $a$}

\begin{tabular}{ll} 
initial causation & preservation \\
\hline 1. natural & natural \\
2. natural & supernatural \\
3. supernatural & supernatural \\
4. supernatural & natural
\end{tabular}

Case (1) was discussed in Sect. 2.1: a thing $a$ naturally causes and preserves an intuition as long as it is present to the subject. Case (2) was discussed in this section: the intuition of a thing is naturally caused by $a$, but supernaturally sustained by God. I now turn to the supernatural affirmative case, case (3). ${ }^{48}$

\footnotetext{
47 Ockham discusses cases (1) to (3) in Rep. II, qq.12-13 (OTh V, 258-261)

48 It should be noted that, according to Ockham's theory, case (3) may also include negative judgements: God could supernaturally cause and preserve in my intellect the intuition of a thing that does not exist, in which case I would judge correctly that this thing does not exist. I thank one of the reviewers for pointing this out to me.
} 


\subsection{The Supernatural Affirmative Case}

In his Reportatio, Ockham presents a supernatural case where the thing intuited exists without being present to the subject. He writes:

[...] If God were to cause in me an intuitive cognition of a thing existing in Rome, then I could judge that the thing I am intuiting and seeing exists, on the basis of the intuitive cognition of it, just as well as if that cognition would be had naturally. If you say that this object is neither presently here, nor sufficiently near, I answer: although the intuitive cognition cannot be caused naturally unless the object is present in some determinate distance, it can be [caused] supernaturally [in the absence of its object]. ${ }^{49}$

As Ockham points out, a thing can act as a natural cause of an intuition only if it is sufficiently near to the intuiting subject. In this supernatural case, however, God causes an intuition of a thing $a$ (in Rome) within a subject being in another city (in Hamburg, let's say). That is, if God causes in Anne (being in Hamburg) an intuition of the pope (being in Rome), then this intuition causes Anne to judge evidently that he (the pope) exists. Recall that in the natural affirmative case, a subject judging evidently that $a$ exists in the presence of $a$ is ready to judge evidently that $a$ is present or that $a$ is here. ${ }^{50}$ This is not so in this supernatural case. For one thing, it is simply not true that the pope is present (to Anne). The question is whether Anne is in a position to judge evidently about the pope's spatial position or his relation to other things at all. Above I held that the natural cause of an intuitive act can be rather complex, since everything present to a subject can exert its causal powers in the production of one and the same intuitive act. ${ }^{51}$ But here, God supernaturally produces the intuition of exactly one thing in the subject, since he replaces just one thing as a cause. It is a salient feature of supernaturally induced intuition that a subject can intuit one thing in total isolation, without even in relation to its spatial position, if that thing exists. It is not contradictory that God could cause an intuition of exactly one thing within a subject, that is, without causing an intuition of the thing's actual position or in general, of the thing's surrounding. As Ockham emphasizes, it is not contradictory that 'a thing is seen without (the) situation, at least by divine power $[\ldots]^{52}$

Why does the intuition of $a$ (existing, but not present to the subject) cause the subject to judge evidently that

\footnotetext{
${ }^{49}$ Rep. II, qq.12-13 (OTh V, 258).

${ }^{50}$ See (2) Sect. 2.1 above.

51 See Sect. 2.1.

52 Rep. II, qq.12-13 (OTh V, 284).
}

$a$ exists? Normally, a thing $a$ does not only cause the intuition of it in a subject, but $a$ together with the intuition of $a$ causes the subject to judge evidently that $a$ exists. If, however, $a$ exists, but is not present to the subject, then $a$ cannot naturally exert any of these two causal powers. If $a$ exists, but is not present to a subject, then God can replace the object of intuition in both respects while causing the intuition in the subject as well as the evident judgement that $a$ exists, if $a$ exists. Again, one could say that God causes the judgement indirectly insofar as he directly causes the intuition of a, which in turn, directly causes the judgement. God is able to do this because it is not contradictory to judge that $a$ exists if $a$ exists. Only, this is a judgement concerning merely the existence of a thing without its presence. As such, it is not naturally attainable. This case can be rendered as follows: ${ }^{53}$

$$
\begin{array}{rl}
a-1 & \mathrm{I}(a) \rightarrow \mathrm{Judg}\left({ }^{\prime} a \text { exists' }\right)_{\mathrm{ev}} \\
\text { (Attention, preoccupation) }
\end{array}
$$

\section{DIAGRAM 4}

In general, supernaturally induced intuition helps us to determine the limits of what can be naturally and evidently known-affirmatively and negatively —on the basis of intuition. It is time to summarize. ${ }^{54}$

\section{Conclusion}

It became clear that according to Ockham, we are able to make both affirmative and negative judgements by natural intuition, just as we are by supernatural intuition. However, it became also clear that these judgements differ as to what exactly they are about: whereas naturally available evident judgements include judgements about the presence or absence of particulars and their presently being or not being thus-and-so, the supernaturally available judgements are about the mere existence or non-existence of things. The latter do not broaden our existential knowledge as to what we have a real chance to know; rather, they are relevant in determining the limits of God's power: God does not have the power to cause incorrect judgements on the

\footnotetext{
53 The broken line between ' $a$ ' and 'God' is meant to indicate that $a$ exists at such a distance that it cannot naturally exert its causal powers on a subject.

${ }^{54}$ I did not discuss case (4) here in which the initial causation of an intuitive act is supernatural, and its preservation natural. Ockham, to my knowledge, nowhere discusses this case. However, we could say that in this case, the intuition of $a$ (existing) is supernaturally caused by God in $a$ 's absence, but then the intuition is further sustained by $a$ (being present). First, the subject can evidently judge that $a$ exists (but not that it is present), and then, when the intuitive act is sustained by $a$, the subject can judge that $a$ is present.
} 
basis of supernaturally induced intuitions in us, since he cannot replace the thing intuited as a (partial) cause of the judgement that $a$ exists, if $a$ does not exist. In Ockham's picture, the divine power to replace any object with respect to at least some of its causal powers should not be a mere logical possibility: God can produce everything that is not contradictory in this world, if he wants to, since he is a free, not a necessary cause. ${ }^{55}$ Therefore, in Ockham's view the intuition both of non-existent and of existing-yet-absent things is to be included in a complete and proper account of the causal powers of intuition, although these two latter cases are only conditional.

Acknowledgements I would like to thank the participants of the conference 'Perception and Negative Beliefs-from Plato to Kant' (Hamburg, August 28-29, 2014) for very helpful discussions on the paper's topics. I would also like to thank the editors and the reviewers for their comments on the text.

Open Access This article is distributed under the terms of the Creative Commons Attribution 4.0 International License (http://crea tivecommons.org/licenses/by/4.0/), which permits unrestricted use, distribution, and reproduction in any medium, provided you give appropriate credit to the original author(s) and the source, provide a link to the Creative Commons license, and indicate if changes were made.

\section{References}

Adams MM (1987) William Ockham. University of Notre Dame Press, Notre Dame

Boehner P (1943) The notitia intuitiva of non-existents according to William Ockham. Traditio 1, pp 223-275, repr. in Boehner (1958), pp 268-300

Boehner P (1945) In propria causa. A reply to Professor Pegis concerning William of Ockham. Franciscan Studies 5, pp 37-45, repr. in Boehner (1958), pp 300-319

Boehner P (1958) In: Buytaert EM (ed) Collected articles. St. Bonaventure, NY

Brower-Toland S (2007) Ockham on judgments, concepts, and the problem of intentionality. Can J Philos 37(1):67-110

Brower-Toland S (2015) How Chatton changed Ockham's mind: William Ockham and Walter Chatton on objects and acts of judgment. In: Klima G (ed) Intentionality, cognition and mental representation in medieval philosophy. Fordham University Press, New York, pp 204-234

Carl W (1974) Existenz und Prädikation-Sprachanalytische Untersuchungen zu Existenz-Aussagen. Beck, München

Day SJ (1947) Intuitive cognition. A key to the significance of the later scholastics. The Franciscan Institute, St. Bonaventure

Dretske F (1969) Seeing and knowing. Routledge and Kegan Paul, London

Gilson E (1937) The unity of philosophical experience. Charles Scribner's Sons, New York
Karger E (1995) William Ockham, Walter Chatton and Adam Wodeham on the objects of knowledge and belief. Vivarium 33(2):171-196

Karger E (1999) Ockham's misunderstood theory of intuitive and abstractive cognition. In: Spade PV (ed) The Cambridge companion to Ockham. CUP, Cambridge, pp 204-226

Karger E (2004) Ockham and Wodeham on divine deception as a skeptical hypothesis. Vivarium 42:225-236

Kneele R (2007) Can God make a Picasso? William Ockham and Walter Chatton on divine power and real relations. J Hist Philos 45(3):395-411

Künne W (1995) Some varieties of thinking. Reflections on Meinong and Fodor in Meinong und die Gegenstandstheorie. Grazer Philosophische Studien 50, Haller R (ed), pp 365-395

McCord Adams M (2001) Ockham on the soul. Proceedings of the American Catholic Philosophical Association 75:43

Michalsky K (1921) Les courants philosophiques a Oxford et a Paris pendant le $\mathrm{XIV}^{\mathrm{e}}$ siecle, Imprimerie de l'Université, Cracovie, repr. in Michalski (1969), pp 1-32

Michalsky K (1969) La philosophie au XIV ${ }^{\mathrm{e}}$ siècle. Minerva GmbH, Frankfurt

Ockham, William of, Ordinatio. Scriptum in Librum Primum Sententiarum, prologus et distinctio prima, Opera Theologica II, ed. S. Brown adlaborante G. Gál, St. Bonaventure, N.Y.: The Franciscan Institute, 1967 (=OTh I)

Ockham, William of, Quodlibeta Septem, Opera Theologica IX, ed. J.C. Wey, St. Bonaventure, N.Y.: The Franciscan Institute, 1980 $(=\mathrm{OTh}$ IX)

Ockham, William of, Reportatio. Quaestiones in Librum Quartum Sententiarum, Opera Theologica VII ed. R.Wood, G. Gál, adlaborante R. Green, St. Bonaventure, N.Y.: The Franciscan Institute, 1984 (=OTh VII)

Ockham, William of, Reportatio. Quaestiones in Librum Secundum Sententiarum, Opera Theologica V, ed. G. Gál, R. Wood, St. Bonaventure, N.Y.: The Franciscan Institute, 1981 (=OTh V)

Ockham, William of, Summa Logicae, Opera Philosophica I, ed. P. Boehner, G. Gál, S. Brown, St. Bonaventure, N.Y.: The Franciscan Institute, 1974 (=OPh I)

Panaccio C (1991) Les Mots, les Concepts et les Choses. Vrin, Paris

Panaccio C (2004) Ockham on concepts. Ashgate, Aldershot

Panaccio C (2009) Le Jugement comme Acte Mental selon Guillaume d'Ockham. In: Biard J (ed) Le Langage Mental du Moyen Age à l'Age Classique. Peeters, Louvain-la-Neuve, pp 117-133

Panaccio C (2010) Intuition and causality: Ockham's externalism revisited. Quaestio 10:241-253

Panaccio C, Piché D (2010) Ockham's reliabilism and the intuition of non-existents. In: Lagerlund $\mathrm{H}$ (ed) Rethinking the history of skepticism: the missing medieval background. Brill, Leiden, pp 97-118

Pegis A (1944) Concerning William Ockham. Traditio 2:465-480

Perler D (2010) Ockham about the soul and its parts. Recherches de Theologie et Philosophie Medievales 77(2):313-350

Schierbaum S (2014) Ockham's assumption of mental speech. Thinking in a world of particulars. Brill, Leiden

Wood R (1987) Intuitive cognition and divine omnipotence: Ockham in fourteenth-century perspective. In: Hudson A, Wilks M (eds) From Ockham to Wyclif. Published for the Ecclesiastical History Society by B. Blackwell, London, pp 51-61

Wood R (1994) Divine power, divine command, and divine goodness according to William Ockham. Philos Jahrb 101(1):38-54

\footnotetext{
55 For a discussion of God as a free cause see Kneele (2007), Wood (1987, 1994).
} 